Jurnal Manajemen dan Bisnis Jayakarta, Volume 1, No. 2, Januari 2020

\title{
FINTECH ERA AND GOVERNMENT REGULATION
}

\author{
Erie Hotman H Tobing', Adrian² \\ Sekolah Tinggi Ilmu Ekonomi Jayakarta ${ }^{1,2}$ \\ tobingerie@gmail.com, atjitranov@gmail.com
}

\begin{abstract}
The growth of Fintech Lending according to OJK data as of November 2019 accumulated loans amounting to Rp 74.54 trillion, an increase of $228.88 \%$ ytd, with 164 registered / licensed operators. Fintech lending illegal that has been acted upon by the Investment Alert Task Force from 2018 to November 2019 as many as 1,898 entities. The latest findings at the end of November 2019 were 125 illegal fintech lending that were not registered in the OJK had been reduced from Google Play. Data from the Indonesian Joint Funding Fintech Association (AFPI) with 164 organizers as of mid-December 2019 noted that there were 25 AFPI members who obtained business licenses from the FSA, while 139 other AFPI members were registered with the FSA through the licensing process.

Ease of access and approval process that is instant compared to approval compared to the banks caused an increase in borrower growth. But behind that, of course there are also many irregularities that occur in illegal organizers.

The effects of fintech's growth have an impact on the growth of conventional banking applications, which are reaching the digital age as well.
\end{abstract}

Keywords: Fintech Lending, OJK Regulation, AFPI

\section{ERA FINTECH DAN REGULASI PEMERINTAH}

\begin{abstract}
ABSTRAK
Pertumbuhan Fintech Lending (Pendanaan Gotong Royong Online) menurut data OJK hingga November 2019 akumulasi jumlah pinjaman mencapai Rp 74,54 Triliun meningkat 228,88\% ytd, dengan jumlah penyelenggara yang terdaftar/berizin 164 perusahaan. Fintech lending ilegall yang suda ditindak oleh Satgas Waspada Investasi sejak tahunn 2018 hingga November 2019 sebanyak 1.898 entitas. Temuan terakhir pada akhir November 2019 sebanyakk 125 fintech lending illegal yang tidak terdaftar di OJK telah diturunakn dari Google Play. Data dari Asosiasi Fintech Pendanaan Bersama Indonesia (AFPI) yang beranggotakan 164 penyelenggara hingga pertengahan Desember 2019 tercatat sudah ada 25 anggota AFPI yang memperoleh ijin usaha dari OJK, sedangkan 139 anggota AFPI lainnya berstatus terdaftar di OJK tengaj melalukan proses perizinan.

Kemudahan dalam mengakses dan proses persetujuan yang instant berbanding persetujuan dibanding pihak perbankan menyebabkan pertumbuhan borrower yang meningkat. Namun dibalik itu tentunya banyak juga terjadi penyimpangan yang terjadi pada penyelenggara illegal.

Efek dari pertumbuhan fintech ini berdampak juga kepada pertumbuhan aplikasi perbankan konvensional yang merambah ke era digital juga.
\end{abstract}

Kata-kata Kunci: Fintech Lending, Regulasi OJK, AFPI

Korespondensi: Adrian, SKom, MMSI. Sekolah Tinggi Ilmu Ekonomi Jayakarta, Jalan Salemba I No.10, RT.4/RW.6, Jakarta 10430. Email: atjitranov@gmail.com 
Jurnal Manajemen dan Bisnis Jayakarta, Volume 1, No. 2, Januari 2020

\section{PENDAHULUAN}

Latar belakang penulisan ini untuk memberikan gambaran mengenai pertumbuhan dari pendanaan berbasis teknologi (Fintech - Finance Technology).

\section{Definisi Fintech}

Fintech adalah sebuah inovasi pada industri jasa keuangan yang memanfaatkan penggunaan teknologi. Produk fintech biasanya berupa suatu sistem yang dibangun guna menjalankan mekanisme transaksi keuangan yang spesifik. ${ }^{[3]}$ Financial Technology / FinTech merupakan hasil gabungan antara jasa keuangan dengan teknologi yang akhirnya mengubah model bisnis dari konvensional menjadi moderat, yang awalnya dalam membayar harus bertatap-muka dan membawa sejumlah uang kas, kini dapat melakukan transaksi jarak jauh dengan melakukan pembayaran yang dapat dilakukan dalam hitungan detik saja.

Pada dasarnya, fintech memiliki banyak layanan dan produk yang bisa dimanfaatkan oleh masyarakat. Namun, berdasarkan Bank Indonesia, fintech ini terbagi menjadi 4 jenis, yakni:

(1) Peer-to-Peer (P2P) Lending dan

\section{Crowdfunding}

P2P lending dan crowdfunding, dikatakan juga sebagai marketplace finansial. Platform seperti ini mampu mempertemukan pihak yang membutuhkan dana dengan pihak yang memberikan dana sebagai modal atau investasi. Biasanya, proses melalui $\mathrm{P} 2 \mathrm{P}$ lending ini lebih praktis karena dapat dilakukan dalam satu online platform.

(2) Manajemen Risiko Investasi

Jenis ini dapat memantau kondisi keuangan dan juga melakukan perencanaan keuangan dengan lebih mudah dan praktis. Jenis manajemen risiko investasi biasanya hadir dan bisa diakses melalui smartphone. Hanya perlu memberikan data yang dibutuhkan untuk bisa mengontrol keuangan yang dibtuhkan.

(3) Payment, Clearing, dan Settlement

Terdapat beberapa startup finansial yang sering menyediakan payment gateaway atau $e$-wallet yang mana kedua produk tersebut masih masuk dalam kategori payment, clearing, dan settlement.

(4) Market Aggregator

Jenis fintech yang saat ini mengacu pada portal yang mengumpulkan beragam informasi terkait keuangan untuk disuguhkan ke target audiens atau pengguna. Biasanya, fintech jenis ini berisi berbagai informasi, tips keuangan, kartu kredit, dan investasi. Dengan adanya fintech jenis ini, diharapkan dapat menyerap banyak informasi sebelum mengambil keputusan terkait keuangan.

\section{METODE}

Metode yang digunakan adalah metode pustaka dan dokumentasi publikasi Internet. 
Jurnal Manajemen dan Bisnis Jayakarta, Volume 1, No. 2, Januari 2020

\section{PEMBAHASAN}

Perkembangan teknologi yang terjadi saat ini tidak hanya disisi perkembangan dari sisi perangkat keras seperti teknologi di telepon selular, namun telah berkembang kedalam bisnis keuangan. Menurut rilis dari OJK perkembangan yang sangat pesat adalah dari Fintech Peer-toPeer Lending atau dalam istilah lain Pendanaan Gotong Royong Online).

Hal ini dapat dilihat dari pertumbuhan perusahaan yang terdaftar / berizin untuk bisnis ini hingga 164 perusahaan.

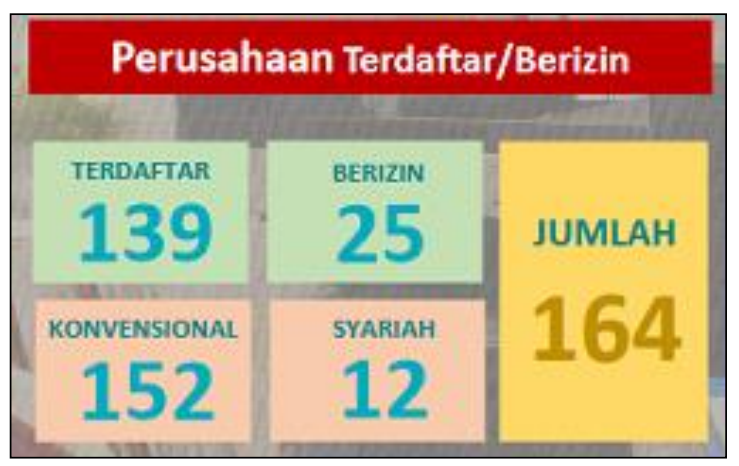

\section{Gambar 1. Perusahaan yang terdaftar/berizin OJK}

Sumber: OJK (2020)

Tentunya perusahaan yang melakukan bisnis illegal menurut data dari Satuan Tugas Waspada Investasi (SWI) hingga tahun 2019, sudah berhasil menghentikan 1949 entitas fintech peer lending illegal. Jika dihitung sejak tahun 2019 hingga Januari 2020 SWI sudah menangani 2018 entitas pinjaman dan investasi illegal, perkembangan aplikasi fintech illegal tersebut tidak hanya melalui aplikasi yang diunduh dari playstore namun juga melalui link unduhan melalui pesan SMS.
Jumlah akumulasi rekening lender hingga Nov 2019 berjumlah 591.662 entitas meningkat $185,13 \%$ ytd. Jika dilihat dari lokasi maka pertumbuhan terbesar dipulau Jawa pertumbuhan diatas $100 \%$, demikian juga untuk lokasi luar jawa mencapai hingga 100\%.

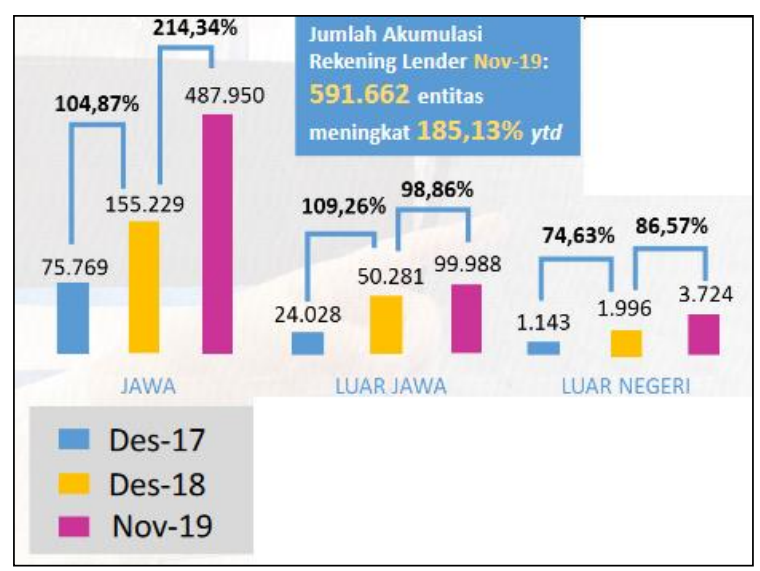

Gambar 2

Jumlah akumulasi rekening lender Sumber: OJK (2020)

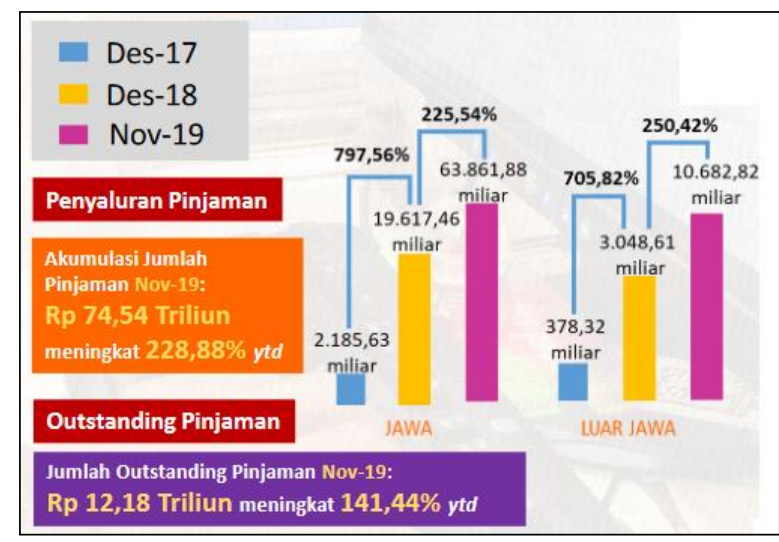

Gambar 3. Pertumbuhan akumulasi rekening lender

Sumber: OJK (2020)

Penyebaran dari pengguna P2P lending ini jika dari melihat usia dan gender, seperti dalam Gambar 4, menunjukkan komposisi lender (pemberi pinjaman) diusia produktif hingga 34 tahun demikian juga dengan borrower 
Jurnal Manajemen dan Bisnis Jayakarta, Volume 1, No. 2, Januari 2020

\begin{tabular}{|c|c|c|c|c|}
\hline \multicolumn{2}{|c|}{ LENDER } & USIA & USIA & BORROWER \\
\hline 8 & 591.662 & & & 17.244 .998 \\
\hline $0^{x}$ & $61,47 \%$ & & & $51,70 \% \sigma^{7}$ \\
\hline 우 & $38,34 \%$ & & & $48,18 \%$ ㅇ \\
\hline 夏 & $0,19 \%$ & 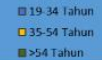 & 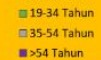 & $0,12 \%$ 夏 \\
\hline
\end{tabular}

Gambar 4. Komposisi pemberi pinjaman dan peminjam berdasarkan usia dan gender Sumber: OJK (2020)

Sedangkan berdasarkan komposisi wilayah baik dari sisi lender maupun borrower seperti digambarkan pada Gambar 5 dan Gambar 6.

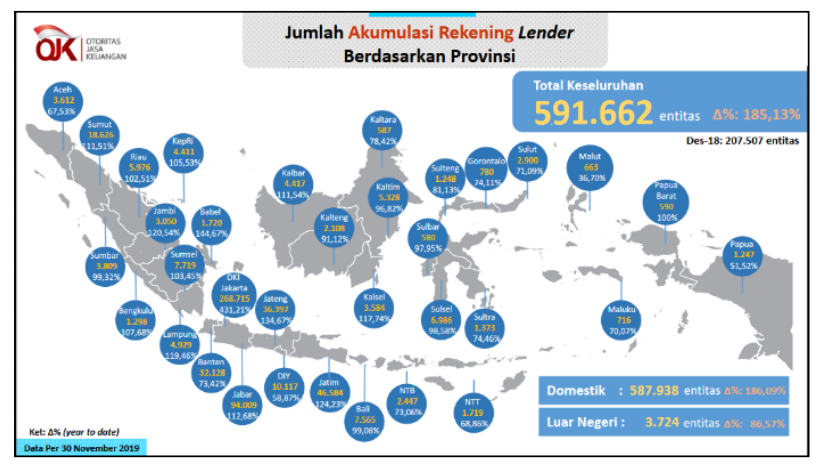

Gambar 5. Komposisi wilayah pemberi pinjaman Sumber: OJK (2020)

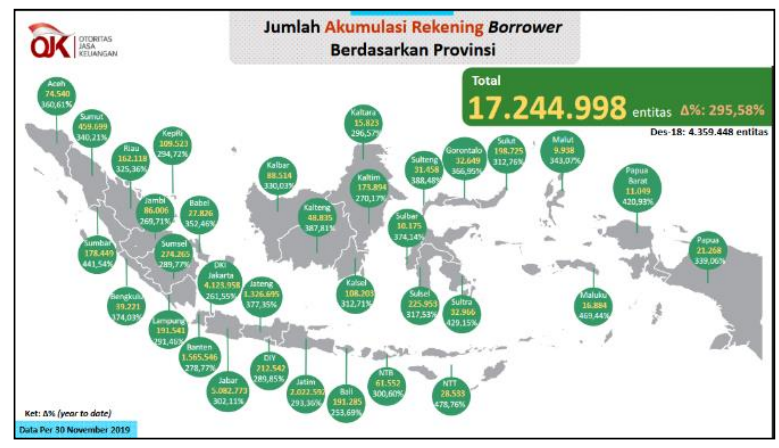

Gambar 6. Komposisi wilayah peminjan Sumber: OJK (2020)

Transaksi yang dilakukan secara umum terjadi dikota-kota besar, seperti Jakarta, Jawa Barat, Banten, Jawa Tengah (Gambar 7)

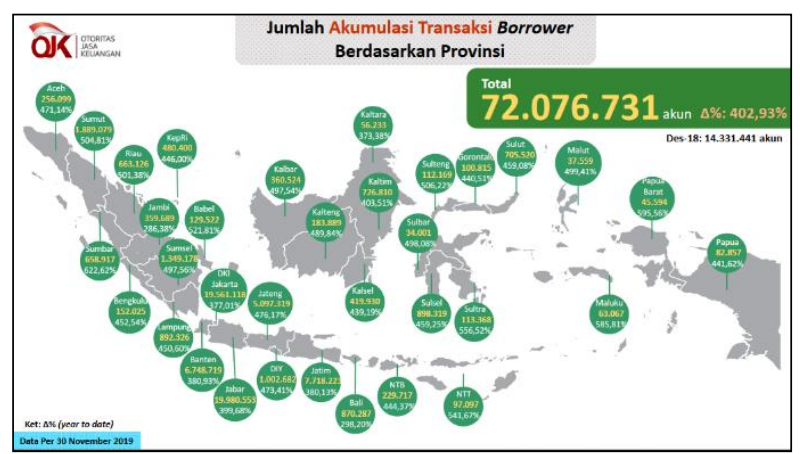

Gambar 7. Komposisi transaksi berdasar wilayah

Sumber: OJK (2020)

Apabila melihat trend yang ada maka ada beberapa alasan yang menyebabkan perkembangan fintech lending ini tumbuh pesat :

(1) Kemudahan dari prosedur yang rumit, dibandingkan peminjaman melalui institusi keuangan baik perbankan atau perusahaan finansial yang lain.

(2) Besarnya kredit yang diberikan memang relatif kecil rata-rata berkisar 3 juta rupiah -8 juta rupiah, tergantung dari hasil Analisa kredit otomatis yang diberikan oleh para peminjamnya.

(3) Besaran suku bunga yang ditetapkan OJK berkisar $1,5 \%$ hingga $2,5 \%$ per bulan.

\section{Perbedaan antara Fintech, Bank dan Multifinance}

Sebelum adanya fintech, masayarakat Indonesia sudah mengenal lembaga keuangan lainnya, yaitu Bank dan Multifinance. 
Jurnal Manajemen dan Bisnis Jayakarta, Volume 1, No. 2, Januari 2020

\section{Bank}

(1) Sumber dananya berasal dari tabungan, deposito, giro, modal pemilik dan penerbitan surat utang.

(2) Layanannya berupa penyaluran kredit, aneka transaksi pembayaran, penjualan aneka produk investasi.

(3) Penyaluran pinjaman ke UMKM, korporasi, konsumsi dan ritel.

(4) Risiko penyaluran pinjaman ditanggung bank.

(5) Diawasi oleh OJK dan Bank Indonesia.

(6) Dana dijamin LPS.

\section{Multifinance}

(1) Sumber dana berasal dari pemilik, perbankan dan penerbitan surat utang.

(2) Layanannya yakni penyaluran pinjaman, beberapa perusahaan sudah melayani berbagai transaksi pembayaran.

(3) Penyaluran pinjamannya berupa sewa guna usaha, pembiayaan usaha,

(4) Pembiayaan konsumsi, dan juga modal ventura.

(5) Risiko penyaluran pinjaman ditanggung oleh miltifinance.

(6) Pengawasnya adalah OJK saja.

(7) Dan tidak ada jaminan untuk dana nasabah.

\section{Fintech}

(1) Sumber dana berasal dari pemilik dan juga para investor.

(2) Layanannya sebagai perantara bagi pemilik dana dan peminjam dana.

(3) Penyaluran pinjaman untuk pembiayaan usaha dan juga bisa untuk pembiayaan pribadi.

(4) Risiko penyaluran pinjaman ditanggung oleh investor.

(5) Pengawasnya hanya OJK, mengawasi dari sisi perlindungan konsumen saja. Jadi saat terjadi masalah dan nasabah atau konsumen yang menjadi korban serta diintimidasi maka bisa langsung melaporkannya pada OJK.

(6) Tak ada jaminan dana nasabah.

\section{Aturan OJK}

Otoritas Jasa Keuangan atau OJK mengeluarkan peraturan terkait teknologi finansial (fintech) :

(1) Nomor 13/POJK.02/2018 tentang Inovasi Keuangan Digital di Sektor Jasa Keuangan, dikeluarkan sebagai ketentuan yang memayungi pengawasan dan pengaturan industri fintech.

(2) POJK 77/POJK.01/2016 Tentang Layanan Pinjam Meminjam Uang Berbasis Teknologi Informasi.

(3) Nomor 21/SEOJK.03/2017 tentang

Penerapan Manajemen Resiko Dalam Penggunaan Teknologi Informasi 
Jurnal Manajemen dan Bisnis Jayakarta, Volume 1, No. 2, Januari 2020

(4) Regulasi Pemerintah mengenai DRC (Disaster Recovery Center) :

(a) Pasal $17 \quad$ PP82/ 2012 tentang Penyelenggara Sistem dan Transaksi Elektronik (PSTE) : kewajiban penempatan Pusat Data dan DRC di wilayah Indonesia.

(b) Pasal 12 Peraturan Bank Indonesia No: 9/15/PBI/2007 perihal Penerapan Manajemen Risiko dalam Penggunaan Teknologi Informasi oleh Bank Umum tentang "Kewajiban Bank melakukan pengendalian fisik dan lingkungan Pusat Data dan DRC."

(c) Pasal 21 Peraturan OJK No: 38/POJK.03/2016 perihal Penerapan Manajemen Resiko dalam Penggunaan Teknologi Informasi oleh Bank Umum tentang "Kewajiban Bank menempatkan Pusat Data dan DRC di Indonesia".

Bagi Penyelenggara Fintech OJK sudah mewajibkan penyelenggara memiliki sertifikasi ISO 27001 mengenai Sistem Manajemen Keamanan Informasi.

\section{KESIMPULAN}

Perkembangan finansial berbasis teknologi menunjukkan adanya trend terhadap perilaku konsumen. Kemudahan yang diberikan baik dari sisi prosedur maupun persetujuan yang cepat meningkatkan pertumbuhan perusahaan yang melakukan bisnis fintech lending.

Untuk melindungi semua pihak, OJK telah membuat sejumlah regulasi baik yang harus dipatuhi oleh penyelenggara dan meminimalkan resiko bagi peminjamnya, meskipun secara resiko berbeda dengan institusi perbankan maupun keuangan yang lain.

\section{DAFTAR PUSTAKA}

Barberis, Janos. \& Chishti, Susanne (2016), The Fintech Book, Wile.

Definisi Fintech menurut Bank Indonesia, diakses dari https://www.bi.go.id/id/edukasiperlindungan-konsumen/edukasi/produk-danjasa-sp/fintech/Pages/default.aspx

Definisi Fintech secara umum https://www.online-pajak.com/fintech

Perkembangan Fintech menurut OJK https://www.ojk.go.id/id/kanal/iknb/data-danstatistik/fintech/Documents/Perkembangan\%20 Fintech\%20Lending\%20Periode\%20November \%202019.pdf

Temuan Fintech illegal, https://www.liputan6.com/bisnis/read/4168057/1 agi-ojk-temukan-120-fintech-ilegal 